Wright State University

CORE Scholar

Biological Sciences Faculty Publications

Biological Sciences

6-1994

\title{
Longitudinal Dynamics of Seston Concentration and Composition in a Lake Outlet Stream
}

Yvonne Vadeboncoeur

Wright State University - Main Campus, yvonne.vadeboncoeur@wright.edu

Follow this and additional works at: https://corescholar.libraries.wright.edu/biology

Part of the Biology Commons, and the Systems Biology Commons

\section{Repository Citation}

Vadeboncoeur, Y. (1994). Longitudinal Dynamics of Seston Concentration and Composition in a Lake Outlet Stream. Journal of the North American Benthological Society, 13 (2), 181-189.

https://corescholar.libraries.wright.edu/biology/581

This Article is brought to you for free and open access by the Biological Sciences at CORE Scholar. It has been accepted for inclusion in Biological Sciences Faculty Publications by an authorized administrator of CORE Scholar. For more information, please contact

corescholar@www.libraries.wright.edu, library-corescholar@wright.edu. 


\title{
Longitudinal dynamics of seston concentration and composition in a lake outlet stream
}

\author{
YVONNE VADEBONCOEUR ${ }^{1}$ \\ Division of Biological Sciences, University of Montana, Missoula, Montana 59812 USA
}

\begin{abstract}
Concentrations of suspended particulate organic carbon (POC), dissolved organic carbon, bacteria, and chlorophyll $a$ were measured in a lake outlet in western Montana, USA. Seven sites within the first $3 \mathrm{~km}$ downstream from the lake were sampled over $14 \mathrm{mo}$. Downstream change in concentration of each variable was tested for fit to a power function $\left(C=a D^{b}\right)$. Downstream changes in POC, bacteria, and chlorophyll $a$, sometimes fit a power function, and the value of the exponent $b$ was positively correlated with discharge. At low discharge, a downstream decline in lake algae was accompanied by an increase in stream algae. At high discharge, concentrations of lake algae did not change downstream, and some stream algae increased. These patterns suggest that although initial concentrations of suspended organic carbon (seston) are determined by the lake, within a short distance, concentrations become regulated by stream processes. As discharge increases, lake products are transported farther downstream. Thus, the extent of the influence of the lake on seston composition expands and contracts longitudinally with increases and decreases in discharge.
\end{abstract}

Key words: lake outlet stream, seston, discharge, POC, bacteria, chlorophyll $a$.

A lake interrupts a stream's longitudinal patterns of organic carbon processing. As a point source of suspended organic carbon (seston), the lake imposes on the outlet stream its own patterns of organic carbon production. The influence of the lake on the composition of the seston is expected to diminish with distance from the lake, while the influences of stream and terrestrial processes are expected to increase. At some point downstream, the influence of the lake on stream seston composition and quantity should be undetectable.

Previous studies of the fate of lacustrine seston in lake outlet streams have emphasized its potential role in maintaining high densities of filter feeders immediately downstream from lakes (see review by Richardson and Mackay 1991). Numbers of lacustrine zooplankton decrease downstream from lakes (Ward 1975, Armitage and Capper 1976, Sandlund 1982, Voshell and Parker 1985, Palmer and O'Keefe 1990), and so do diatoms (Maciolek and Tunzi 1968). Similarly, indices of food quality of seston such as chlorophyll $a$ (Brönmark and Malmqvist 1984), and protein (Valett and Stanford 1987, Kondratieff and Simmons 1984) decrease along a longitudinal gradient, while inorganic sedi-

\footnotetext{
${ }^{1}$ Present address: Department of Biological Sciences, University of Notre Dame, Notre Dame, Indiana 46556 USA
}

ments increase (Richardson 1984). These studies suggest that high quantity and quality of seston exported from the lake are among the factors contributing to high densities of filter feeders in the outlet. However, it is not understood how downstream transport of lake products varies seasonally and what factors influence this variability. If lake exports and seston quality are influencing the distribution of benthic filter feeders, then seasonal patterns of longitudinal transport of lake products may be key to understanding the structure of lake outlet stream communities. For instance, distributions of filter feeders may reflect periods of minimum transport rather than ambient quantity or quality.

Studies on non-outlet streams have demonstrated that the relationships between physical processes and seston concentration are complex. Discharge, channel roughness, availability of particulate organic matter in the stream bed, and the rate and direction of change in discharge all affect seston concentration (Webster et al. 1987). The role of abiotic factors affecting longitudinal patterns of seston transport in lake outlet streams have not been explicitly addressed, although patterns emerge from existing data. For example, downstream persistence of zooplankton increases with increasing discharge (Ward 1975, Armitage and Capper 1976). Despite this, the discussion of 
discharge in lake outlets has focussed primarily on a lake's tendency to damp changes in dischargee to its outlet stream, thus stabilizing the outlet environment (Richardson and Mackay 1991). However, discharge is a component of stream power, which affects the physical ability of the stream to maintain particles in suspension (Leopold et al. 1964) and therefore may affect the distance which lake products are carried downstream.

In this study I examined patterns of seston transport in a lake outlet stream primarily in the context of seasonal changes in discharge. I measured both total seston and two indices of seston quality, chlorophyll $a$ and bacteria. To distinguish between algae exported from the lake and periphyton sloughed from the stream, I identified algae in the seston on two dates. The study was designed to measure these changes within short distances of the lake, over which rapid declines in filter feeders at the study site are known to occur (Sheldon and Oswood 1977, Oswood 1979). Longitudinal and seasonal changes in seston concentration and composition were monitored over 14 mo in a 3-km reach of a lake outlet stream. Because a power function has been shown to describe the downstream decline in filter feeders densities (Sheldon and Oswood 1977) and biomass (Brönmark and Malmqvist 1984), I tested each seston component for fit to a power function on each date.

\section{Methods}

Owl Creek is the outlet of Placid Lake a 400ha mesotrophic lake in western Montana (elevation $1255 \mathrm{~m}$ ). Placid Lake empties into a wide, slowly flowing channel $1 \mathrm{~km}$ long that forms a narrow extension of the lake. At the end of the channel is a $1.5-\mathrm{m}$-high dam which forms a functional boundary between lentic and lotic habitats. The dam is constructed mainly of wooden planks. As well as flowing over the top of the dam, water flows out between the planks along the length of the dam. Owl Creek extends $5 \mathrm{~km}$ from the dam to where it enters the Clearwater River. The average gradient is $1.5 \%$. The study was limited to the first $3 \mathrm{~km}$ of Owl Creek, because it is a relatively uniform reach, with cobble substrate and no tributaries. Riparian vegetation is similar throughout the reach and consists of a mix of willow, alder, and pine.
Because I wanted to test for a logarithmic decline in concentration of lake products, sampling sites were clustered near the lake where the greatest changes in concentration of seston components were expected to occur. Sites were located at the dam and at 50,100,200,450,1500, and $3000 \mathrm{~m}$ downstream from the dam. Because of time limitations, it was not possible to measure discharge on sampling dates. Therefore, I placed a staff gauge at the $200-\mathrm{m}$ site and developed a discharge rating curve. I measured current velocity at $0.5-\mathrm{m}$ intervals across the stream with a Gurley Pygmy current meter at $0.6 \times$ depth and multiplied by cross sectional area to calculate discharge. Discharges used to develop the rating curve ranged from $0.1 \mathrm{~m}^{3} / \mathrm{s}$ to $5.2 \mathrm{~m}^{3} / \mathrm{s}$ and the regression was significant $\left(r^{2}=0.97, p<0.005\right)$. On three dates discharge was measured at both $200 \mathrm{~m}$ and $3000 \mathrm{~m}$ to assess whether discharge changed over the reach. Differences in upstream-downstream discharge measurements were compared with differences in multiple within-site measurements at $200 \mathrm{~m}$.

At all seven sites, organic carbon, bacteria, and/or chlorophyll $a$ were sampled on eight dates between November 1984 and January 1986 (Table 1). Sample dates were chosen to include spring and fall high-discharge events, and midwinter and mid-summer low flows. All samples were grab samples collected in the thalweg over the entire depth of the water column. I collected samples at the upstream end of a riffle within each site to minimize the effects of differences in stream morphology on measured seston concentrations among sample sites. A mixture of depositional and erosional sites might have confounded downstream changes in seston, and I was not interested in these smaller-scale changes in seston.

I collected organic carbon samples $(n=2$ per site) in acid-washed 300-mL glass BOD bottles. Samples were fixed immediately in the field with sulfuric acid and stored at $4^{\circ} \mathrm{C}$ until analyzed. Two aliquots from each sample of particulate organic carbon (POC) were filtered onto pre-ashed $0.45-\mu \mathrm{m}$ glass fiber filters (Gelman A/E). Each filter was sealed in a pre-ashed 10$\mathrm{mL}$ glass ampule with $10 \mathrm{~mL}$ of carbon-free water and an oxidizing agent (potassium persulfate). For dissolved organic carbon (DOC) two 10-mL aliquots of the filtrate from each sample were sealed in pre-ashed glass ampules with 
potassium persulfate. All ampules were autoclaved to convert the organic carbon to $\mathrm{CO}_{2}$. POC or DOC was measured as evolved $\mathrm{CO}_{2}$ on an Oceanography International TOC analyzer (Menzel and Vaccaro 1964).

Bacteria samples ( $n=2$ or 3 per site) were collected in acid-washed 30-mL Nalgene ${ }^{\circledR}$ bottles and fixed in the field to a final concentration of $2 \%$ formaldehyde. I separately counted bacteria that were unattached and attached to particles, using the acridine orange method (Hobbie et al. 1977).

Each chlorophyll a sample ( $n=3$ per site) consisted of 1-3 L of water collected in plastic bottles. Immediately upon reaching the lab, samples were filtered through glass fiber filters (Whatman GF/C, 1.2- $\mu \mathrm{m}$ nominal pore size) and analyzed according to the methanol extraction method of Holm-Hansen and Riemann (1978). Chlorophyll a concentrations were not measured on the sampling dates in July and September, 1985. Instead, 1-L samples were collected at the dam and 100, 450, and $3000 \mathrm{~m}$ downstream from the dam, and fixed with $\mathrm{Lu}$ gol's solution for algal cell counts. Aliquots of each sample were filtered onto a membrane filter (Millipore HA, $0.45-\mu \mathrm{m}$ pore size) for counting. Algae were identified to genus or species using the taxonomic keys of Patrick and Riemer (1966), Prescott (1982), and Smith (1950).

For each date, a power function $\left(C=\mathrm{aD}^{b}\right.$, where $C=$ concentration of a given variable, $D$ $=$ distance downstream from the lake, and a and $b$ are constants) was tested for fit to downstream changes in each variable. Means of within-site values for each variable were regressed on distance using SYSTAT statistical software. Because I identified algae in the seston at only 4 sites, I did not test for fit to a power function but instead tested for downstream change using Spearman's rank correlation coefficient.

A power function predicts infinite seston concentrations at a distance of zero. This necessitated a transformation of the distance value for the first site from $0 \mathrm{~m}$ to some positive number. Directly below the dam Owl Creek opens into a wide, deep pool that extends $20 \mathrm{~m}$ downstream. The pool is more similar to the habitat above the dam than to any downstream habitat in the study reach. In the analysis the distance value for the upstream site was reassigned from 0 to $20 \mathrm{~m}$, the start of typical stream habitat. The inherent assumption in this manipulation
TABLE 1. Discharge and seston components sampled on each date. POC = particulate organic carbon, $\mathrm{DOC}=$ dissolved organic carbon, $\mathrm{Algae}=$ taxonomic identification of algae.

\begin{tabular}{ccl}
\hline \hline & $\begin{array}{c}\text { Dis- } \\
\text { charge } \\
\left(\mathrm{m}^{3} / \mathrm{s}\right)\end{array}$ & \multicolumn{1}{c}{ Variables sampled } \\
\hline Sample date & 0.20 & POC, DOC, Chlorophyll $a$ \\
26 Nov. 1984 & 0.42 , DOC, Chlorophyll $a$ \\
3 Mar. 1985 & 0.42 & $\begin{array}{l}\text { POC, Dacteria } \\
\text { Bach }\end{array}$ \\
14 Apr. 1985 & 6.48 & POC, DOC, Bacteria \\
5 May 1985 & 6.01 & POC, DOC, Chlorophyll $a$ \\
21 June 1985 & 1.26 & POC, DOC, Chlorophyll $a$ \\
14 July 1985 & 0.34 & Bacteria, Algae \\
24 Sep. 1985 & 2.17 & Bacteria, Algae \\
18 Jan. 1986 & 0.82 & POC, DOC, Chlorophyll $a$, \\
& & Bacteria \\
\hline
\end{tabular}

is that there is little or no change in seston concentration as water travels through the pool.

A positive value of $b$ indicates a downstream increase in concentration while a negative value indicates a downstream decrease. The absolute value of $b$ indicates the rapidity of this change. To test whether there was a relationship between discharge and the rate and direction of downstream changes in seston components, I regressed the $b$ values for POC, bacteria and chlorophyll $a$ on the natural log of discharge. I included $b$ values from regressions for which there was no significant difference among sites (i.e., $b$ was not significantly different from zero). Because the $b$ values were derived from three sources (POC, bacteria, and chlorophyll a), the initial regression was a stepwise multiple regression. The independent variables were the natural log of discharge and a dummy variable coding for POC, bacteria, or chlorophyll $a$.

\section{Results}

\section{Discharge and seston concentration}

Discharge in Owl Creek is strongly influenced by spring snowmelt (Fig. 1). Downstream changes in seston concentrations could potentially be driven by longitudinal changes in discharge due to influx of ground water or tributaries. However, Owl Creek has no tributaries. On the three dates for which measurements at both upstream and downstream sites were made, there was no significant downstream change in 


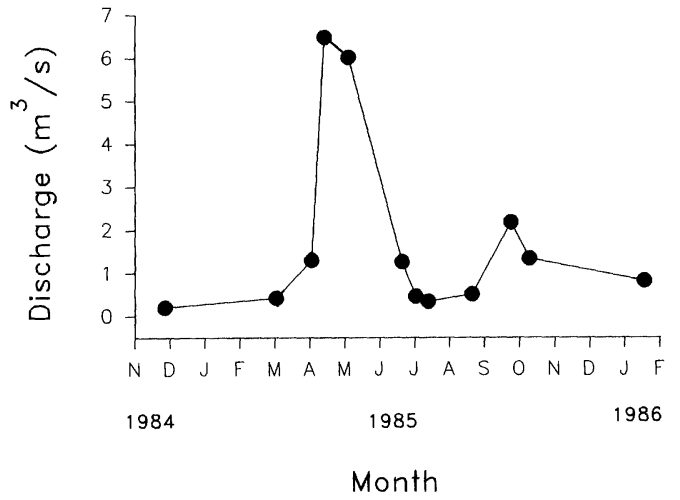

Fig. 1. Hydrograph for Owl Creek during the study.

discharge. Discharge on these three dates was $\leq 1.1 \mathrm{~m}^{3} / \mathrm{s}$. It is unlikely that any downstream decrease in seston concentration during low flow is due to dilution by an influx of groundwater. Because discharge data were not collected at upstream and downstream sites during high flow, I cannot assess whether ground-water influx was significant at these times. However, during high discharge, seston concentrations tended to increase or stay the same longitudinally (Figs. 2, 3,4). These patterns argue against significant dilution by groundwater influx.

Of the dates sampled, November 1984 had the lowest discharge and the greatest downstream decrease in POC (Fig. 2). In March 1985, just before spring runoff, there was no significant longitudinal change in POC. In April, on the rising limb of the hydrograph, POC appeared to increase downstream from the lake, but the regression was not significant $(p>0.05)$. On the falling limb of the hydrograph in May, a power function significantly fit downstream increases in POC. In June, a significant reduction in POC occurred downstream from the lake. By midwinter (January) longitudinal patterns had returned to the early spring condition of no downstream change. Concentrations of DOC did not change significantly over distance on any date. Mean DOC concentrations for the study reach ranged from $3.7 \mathrm{mg} / \mathrm{L}$ in April to $5.2 \mathrm{mg} / \mathrm{L}$ in May. The average concentration over the 14-mo study period was $4.7 \mathrm{mg} / \mathrm{L}$.

\section{Seston quality}

Suspended bacteria unattached to particles did not follow a power function during the April

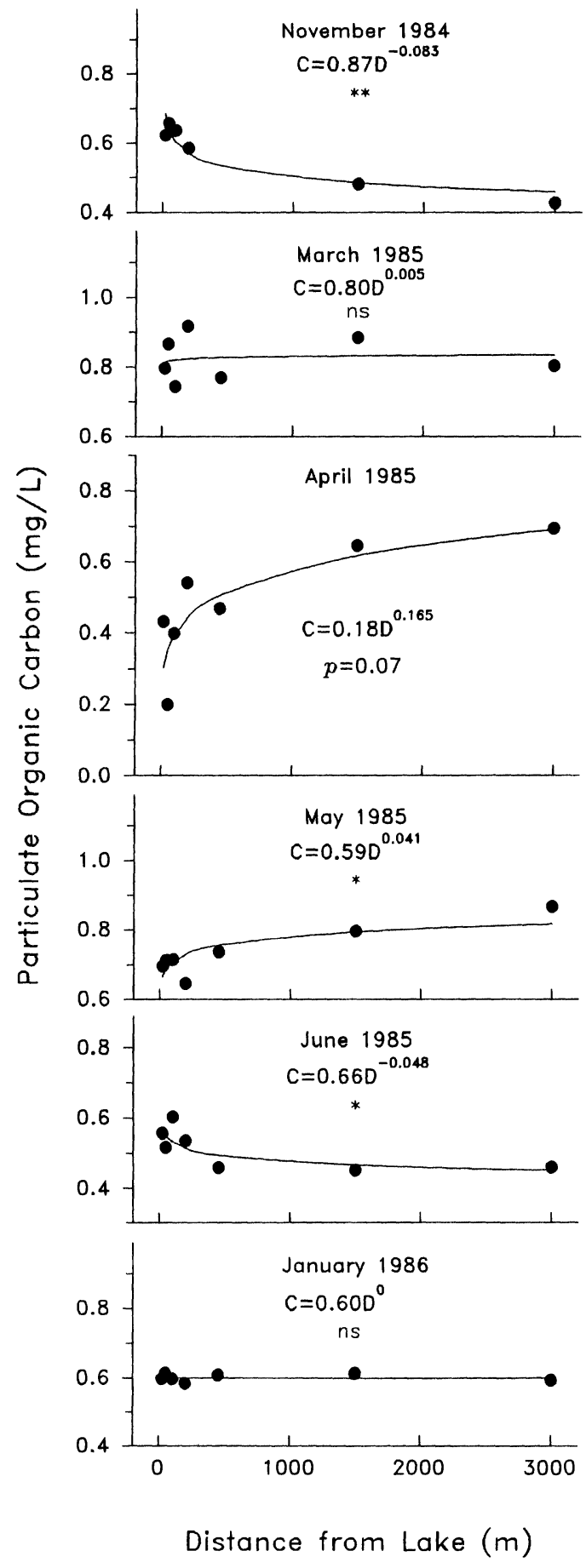

FIG. 2. Longitudinal changes in particulate organic carbon (POC) concentration downstream from Placid Lake. A power function is fitted to the data, where $\mathrm{C}=$ concentration, and $\mathrm{D}=$ distance. ${ }^{*} p<$ $0.05,{ }^{* *} p<0.01, \mathrm{~ns}=$ not significant. 
peak discharge nor during the secondary discharge peak in September (Fig. 3). On other dates, concentrations of free bacteria declined downstream, and power functions fit the data. Bacterial concentrations peaked for the year in July at $3.1 \times 10^{9} / \mathrm{L}$, and the downstream decline in bacteria was most marked on this date. Bacteria attached to particles were counted in April, July, and January. Concentrations of attached bacteria were 1-2 orders of magnitude lower than concentrations of unattached bacteria. No significant downstream changes in bacteria attached to particles occurred on any of the dates.

The highest concentrations of chlorophyll $a$ exported from the lake occurred in March and a power function significantly fit the subsequent downstream decline in chlorophyll $a$ (Fig. 4). In May, a power function also fit the downstream changes, but chlorphyll $a$ increased. There was no significant fit of a power function to chlorphyll $a$ data in November, June, or January.

In July and September suspended algae at the dam and at sites $100 \mathrm{~m}, 450 \mathrm{~m}$, and $3000 \mathrm{~m}$ were counted. In July Chroomonas and Anabaena were the most abundant of the algae that originated from the lake. The predominant benthic stream alga was Cocconeis placentula var lineata. Other benthic diatoms were less abundant and were grouped together for analytical purposes. This group included Gomphonema, Epithemia, Cymbella, Navicula radiosa, and Cocconeis pediculus. Cocconeis placentula and other benthic diatoms increased with distance from the lake. In contrast, the lake algae Chroomonas and Anabaena decreased downstream (Table 2).

In September, the most abundant lake algae in the seston were still Anabaena and Chroomonas. In addition Staurastrum, Ceratium, and Gymnodinium were present. Again I divided stream algae into two groups, Cocconeis placentula and other benthic diatoms. Anabaena and Chroomonas were transported downstream without significant changes in concentration. Cocconeis placentula also showed no longitudinal change. Other benthic diatoms increased significantly downstream (Table 2).

Use of power functions and their correlation with discharge

A power function significantly fit the data for $50 \%$ of the data sets (Figs. 2-4). However, a lack

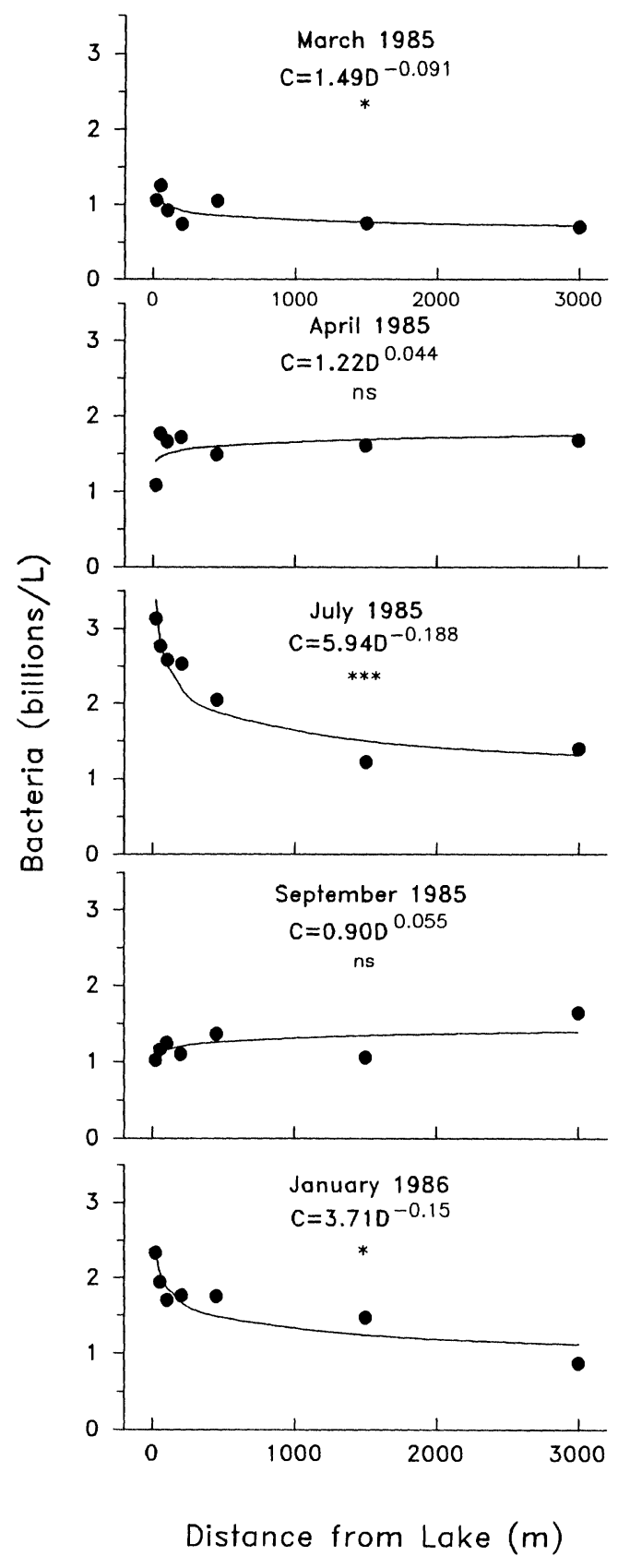

FIG. 3. Longitudinal changes in the concentration of unattached bacteria. A power function is fitted to the data, where $\mathrm{C}=$ concentration, and $\mathrm{D}=$ distance. ${ }^{*} p<0.05,{ }^{* * *} p<0.001, \mathrm{~ns}=$ not significant.

of significant fit could result either from lack of downstream change in the variable (i.e., the exponent $b=0$ ) or from the downstream changes not being adquately described by a power func- 


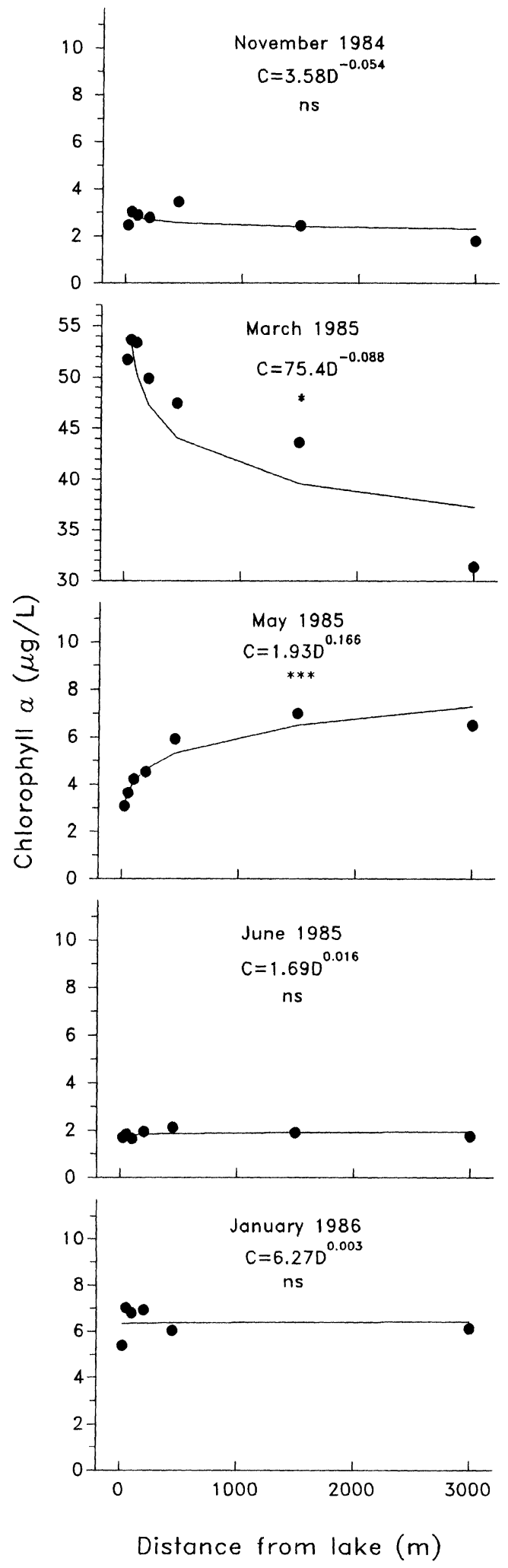

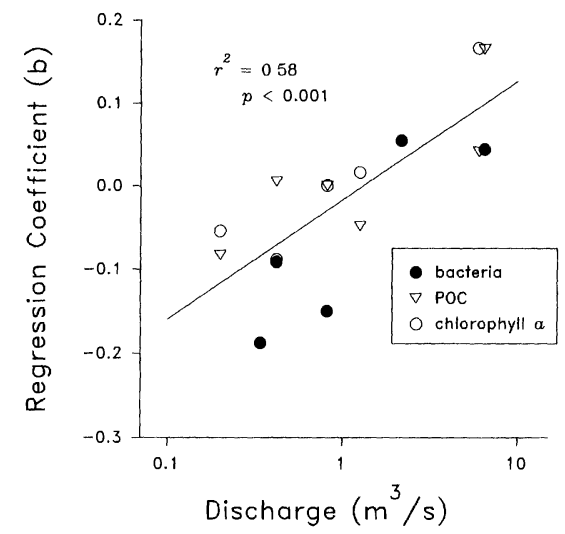

FIG. 5. Regression of the exponent $b$ (from the power function $C=\mathrm{aD}^{b}$ ), from POC, bacteria, and chlorophyll a (Figs. 2, 3,4), on the natural log of discharge.

tion. Lack of replication does not allow for the separation of these two issues. The regression of the exponent $b$ on natural log of discharge was significant $(p<0.001)$ and the effect of the dummy variable coding for bacteria, chlorophyll $a$, or bacteria was not $(p>0.1)$. The exponent $b$ increased with increasing discharge (Fig. 5).

\section{Discussion}

A power function proved to be a useful tool to describe longitudinal changes in POC, bacteria and chlorophyll $a$. Whether seston components increase or decrease with distance from the lake, a power function predicts that the rate of change in concentration will decline with distance. The exponent $b$ is a dimensionless number that indicates the direction and the magnitude of the rate of change in seston concentration. As such it provided an ideal way to simplify the comparison of the diverse and complex patterns of seston dynamics observed in this study. Fifty eight percent of the variation in $b$ was explained by discharge (Fig. 5). The strongest pattern that emerges from the data is that initial concentrations of seston exported from the lake are depleted or augmented in the stream as a function of discharge.

FIG. 4. Longitudinal changes in chlorophyll $a$ concentration. $\mathrm{C}=$ concentration, and $\mathrm{D}=$ distance. ${ }^{* *} p$ $<0.01,{ }^{* * *} p<0.001, \mathrm{~ns}=$ not significant. 
TABLE 2. Changes in taxonomic composition of algae in the seston downstream from the dam during summer low flow (July) and during the fall secondary discharge peak (September) in 1985. Anabaena sp. and Chroomonas sp. are lake algae. Cocconeis placentula and other benthic diatoms are benthic stream algae.

\begin{tabular}{|c|c|c|c|c|c|c|}
\hline \multirow[b]{2}{*}{ Date } & \multirow[b]{2}{*}{$\begin{array}{l}\text { Discharge } \\
\left(\mathrm{m}^{3} / \mathrm{s}\right)\end{array}$} & \multirow{2}{*}{$\begin{array}{l}\text { Distance } \\
\text { from lake } \\
\quad(\mathrm{m})\end{array}$} & \multicolumn{4}{|c|}{ Algal cell concentration (thousands/L) } \\
\hline & & & Anabaena sp. & $\begin{array}{l}\text { Chroomonas } \\
\text { sp. }\end{array}$ & $\begin{array}{l}\text { Cocconeis } \\
\text { placentula }\end{array}$ & $\begin{array}{c}\text { Other benthic } \\
\text { diatoms }\end{array}$ \\
\hline \multirow[t]{4}{*}{ July } & 0.34 & 20 & 149 & 135 & 5.50 & 1.50 \\
\hline & & 100 & 53.6 & 132 & 10.8 & 1.77 \\
\hline & & 450 & 61.0 & 102 & 44.3 & 5.27 \\
\hline & & 3000 & 9.17 & 26.8 & 123 & 33.3 \\
\hline \multicolumn{2}{|c|}{$\begin{array}{l}\text { Spearman's rank correla- } \\
\text { tion coefficient }\left(r_{\mathrm{s}}\right)\end{array}$} & & $\begin{array}{c}-0.8 \\
p<0.05\end{array}$ & $\begin{array}{c}-1.0 \\
p<0.05\end{array}$ & $\begin{array}{c}1 \\
p<0.05\end{array}$ & $p<0.05$ \\
\hline \multirow[t]{4}{*}{ September } & 2.2 & 20 & 1090 & 78.1 & 11.2 & 1.70 \\
\hline & & 100 & 1310 & 60.5 & 12.6 & 2.67 \\
\hline & & 450 & 1180 & 74.0 & 7.79 & 3.01 \\
\hline & & 3000 & 1220 & 65.5 & 21.8 & 14.8 \\
\hline \multirow{2}{*}{\multicolumn{3}{|c|}{$\begin{array}{l}\text { Spearman's rank correla- } \\
\text { tion coefficient }\left(r_{\mathrm{s}}\right)\end{array}$}} & 0.4 & -0.4 & 0.4 & 1 \\
\hline & & & ns & ns & ns & $p<0.05$ \\
\hline
\end{tabular}

Factors other than discharge might explain some of the remaining variation in the magnitude of $b$. If initial concentrations of POC are similar to the concentration that can remain suspended in the stream at that discharge, downstream changes in concentration will be minimal. Conversely, if the initial concentration of any component is much higher or lower than what can eventually be maintained by the stream, the absolute value of $b$ will be relatively large, or lake products will be carried a greater distance downstream. This is seen in the relationship between the value of $b$ for bacteria in March, July, and January. As initial concentration increases, the absolute value of $b$ increases. Similarly in March very high initial concentrations of chlorophyll a resulted in a marked downstream decrease. In March, chlorophyll a concentrations exported from the lake were twenty times higher than concentrations maintained in the stream throughout the rest of the year. This is similar to the findings of Brönmark and Malmqvist (1984) who detected significant decreases in chlorophyll $a$ below a lake only when concentrations exceeded $30 \mu \mathrm{g} / \mathrm{L}$.

The positive correlation between $b$ and discharge may represent variation in the relative influence of retention versus entrainment mechanisms in the stream. As discharge (and hence stream power) increases, the ability of the stream to suspend more and larger particles also increases (Leopold et al. 1964). This pushes the dynamic between retention and transport towards transport. In May the POC exported from the lake was augmented downstream, as was chlorophyll $a$. In contrast, at discharges lower than $1 \mathrm{~m}^{3} / \mathrm{s}, b$ tends to be negative, indicating that seston is being retained in the study reach. Several mechanisms may explain this pattern. As the stream loses power, resuspension of particles from the benthos decreases and sedimentation increases. Mean depth decreases, decreasing water volume per unit surface area of stream bottom. This increases the probability that a particle in transport will encounter biological or physical retention mechanisms associated with the stream bed. In November, at very low flow, POC concentrations dropped rapidly downstream from the lake. Whether this reduction in POC concentration is typical of Owl Creek at low flow is difficult to ascertain. The only flows similar to November occurred in July, and POC data were not obtained on this date. However, even if total seston concentrations do not decline downstream, retention mechanisms affect seston composition at flows below $1 \mathrm{~m}^{3} / \mathrm{s}$. This can be seen in the longitudinal declines in bacteria in March, July, and January and in the declines in chlorophyll $a$ in March and lake algae in July. 
The exponent $b$ is expected to be less than or equal to zero for seston components originating in the lake. Recruitment of stream algae into the seston was substantial, making chlorophyll $a$ a poor tracer of lake phytoplankton. Lake algae could be distinguished from stream algae in the direct counts. In July, lake algae in the seston tended to decline downstream, while benthic diatoms increased significantly. In contrast, during high discharge in September, lake algae were transported through the sample reach with minimal changes in concentration. The origin of the bacteria could not be determined with the methods I used. Potential downstream sources include recruitment from the benthos and reproduction of bacteria in the water column. However, below discharges of $1 \mathrm{~m}^{3} / \mathrm{s}$, bacterial concentrations were not maintained at lake levels. No significant positive value of $b$ was obtained for bacteria on any sample date (Fig. $3)$. These patterns are consistent with the patterns that would be expected if the lake were the predominant source of bacteria in Owl Creek.

The influence of the lake can be considered to expand and contract with discharge. The downstream decline in bacteria in March, July, and January, along with the decline in chlorophyll $a$ in March and lake algae in July, is evidence that lake exports are rapidly removed from the seston when discharge is less than 1 $\mathrm{m}^{3} / \mathrm{s}$. Discharge in Owl Creek is maintained at such levels for long periods in the summer and winter. If the gradients observed in this study are maintained throughout these periods of low discharge, they may contribute to similar gradients in filter feeder density and production. Suspended bacteria are a food source for black flies (Fredeen 1964, Edwards and Meyer 1987) and blackflies show marked longitudinal declines in abundance in Owl Creek (Sheldon and Oswood 1977).

The lake outlet can be viewed as a transition zone between an area in which seston composition is determined by lake processes and one in which seston composition reflects the stream's processing of organic matter. When considering the effect of lake seston on lake outlet benthos, researchers must keep in mind that patterns of transport vary over time and are a function of discharge, distance from the lake, and initial concentration of lake exports.

\section{Acknowledgements}

I wish to thank Andrew L. Sheldon for guidance and advice during all stages of this study. I also thank J. A. Stanford, D. Kilgore, D. Potts, V. Watson, K. Foresman, and R. Juday for their advice and for generously making their laboratory facilities available to me. Thanks also to Gary A. Lamberti for his helpful comments on the manuscript. The comments of two anonymous reviewers substantially improved the manuscript. This research was supported, in part, by a grant from the University of Montana Graduate School and was done in partial fulfillment of a Master of Arts degree at the University of Montana, Missoula.

\section{Literature Cited}

ARMtTAge, P. D., AND M. H. CAPPER. 1976. The numbers, biomass and transport downstream of micro-crustaceans and Hydra from Cow Green Reservoir (Upper Teesdale). Freshwater Biology 6:425-432.

BRÖNMARK, C., AND B. MALMQVIST. 1984. Spatial and temporal patterns of lake outlet benthos. Verhandlungen der Internationalen Vereinigung für Theoretische und Angewandte Limnologie 22: 1986-1991.

EDWARDS, R. T., AND J. L. MEYER. 1987. Bacteria as a food source for black fly larvae in a blackwater river. Journal of the North American Benthological Society 6:241-250.

FREDEEN, F. J. H. 1964. Bacteria as food for blackfly (Diptera:Simuliidae) larvae in laboratory culture and in natural streams. Canadian Journal of Zoology 42:527-548.

Hobbie, J. E., R. J. DAley, AND S. JAsper. 1977. Use of Nuclepore filters for counting by fluorescence microscopy. Applied and Environmental Microbiology 33:1225-1228.

Holm-HANSEN, O., AND B. RiemanN. 1978. Chlorophyll $a$ determination: improvements in methodology. Oikos 30:438-447.

KondRATIEFF, P. F., AND G. M. Simmons. 1984. Nutritive quality and size fractions of natural seston in an impounded river. Archiv für Hydrobiologie 101:401-412.

Leopold, L. B., M. G. Wolman, J. P. Miller. 1964. Fluvial processes in geomorphology. W. H. Freeman and Company, San Francisco.

MACIOLEK, J. A., AND M. G. TUNZI. 1968. Microseston dynamics in a simple Sierra Nevada lake-stream system. Ecology 49:60-75.

MenZEL, D. W., AND R. F. VACCARO. 1964. The mea- 
surement of dissolved organic and particulate carbon in sewater. Limnology and Oceanography 9:138-142.

OswooD, M. W. 1979. Abundance patterns of filter feeding caddisflies (Trichoptera:Hydropsychidae) and seston in a Montana (USA) lake outlet. Hydrobiologia 63:177-183.

PALMER, R., AND J. O'KeEFE. 1990. Transported material in a small river with multiple impoundments. Freshwater Biology 24:563-575.

PATRICK, R., AND C. W. ReIMER. 1966. The diatoms of the United States, Volume I. Livingston Publishing Company, Philadelphia.

PrescotT, G. W. 1982. Algae of the western Great Lakes area. Otto Koeltz Science Publishers, Königstein, Germany.

RICHARDSON, J. S. 1984. Effects of seston quality on the growth of a lake-outlet filter feeder. Oikos 43:386-390.

RICHARDSON, J. S., AND R. J. MACKAY. 1991. Lake outlets and the distribution of filter feeders: an assessment of hypotheses. Oikos 62:370-380.

SANDLUND, O. T. 1982. The drift of zooplankton and microzoobenthos in the river Strandaelva, western Norway. Hydrobiologia 94:33-48.

SHELDON, A. L., AND M. W. Oswood. 1977. Blackfly (Diptera:Simuliidae) abundance in a lake outlet: test of a predictive model. Hydrobiologia 56:113120.

SMITH, G. M. 1950. The freshwater algae of the United States. McGraw Hill Book Company, Incorporated, New York.

VALETT, H. M., AND J. A. STANFORD. 1987. Food quality and hydropsychid caddisfly density in a lake outlet stream in Glacier National Park, Montana, USA. Canadian Journal of Fisheries and Aquatic Sciences 44:77-82.

VOSHell, J. R., AND C. R. PARKeR. 1985. Quantity and quality of seston in an impounded and a freeflowing river in Virginia, U.S.A. Hydrobiologia 122:271-280.

WARD, J. V. 1975. Downstream fate of zooplankton from a hypolimnial release mountain reservoir. Verhandlungen der Internationalen Vereinigung für Theoretische und Angewandte Limnologie 19:1798-1804.

Webster, J. R., E. F. BENFIELD, S. W. Golladay, B. H. HILL, L. E. HORNICK, R. F. KAZMIERCZAK, AND W. B. PERRY. 1987. Experimental studies of physical factors affecting seston transport in streams. Limnology and Oceanography 32:848-863.

Received: 9 December 1992 Accepted: 3 February 1994 